\title{
ASSESSING THE LINK OF TRAINING AND DEVELOPMENT WITH ADAPTIVE AND CONTEXTUAL PERFORMANCE IN THE PRESENCE OF ORGANIZATION POLITICS
}

\author{
Munaza Bibi \\ PhD. Scholar, Department of Management Studies \\ Bahria University, Karachi Campus \\ munaza.12star@yahoo.com \\ Rafique Ahmed Khan \\ Professor, Department of Business Studies \\ Bahria University, Islamabad Campus \\ rak.buic@bahria.edu.pk
}

\begin{abstract}
This study is focused on assessing the adaptive and contextual performance as an outcome of training and development via keeping organization politics as a mediator. For the assessment of the proposed link data were gathered from 379 healthcare professionals working in public sector hospitals using the deductive approach. The outcomes of the study disclosed that training and development have a considerable influence on both facets of employee performance that is adaptive and contextual. Likewise, the link between training and development, adaptive performance, and contextual performance has been mediated by nepotism and favoritism: the form of organization politics. Therefore, results portray that during executing the training and development practices management must be cautious to timely organize the programs as per the needs of employees as it eventually affects the employee's performance. Additionally, the existing study is of worth for the managers who manage human resources of the hospital to frame a strategy to rheostat this phenomenon in the organization as it eventually determines the performance of an employee.
\end{abstract}

Keywords: Training and Development, Organization Politics, Nepotism, Favoritism, Adaptive Performance, Contextual Performance.

\section{INTRODUCTION}

One of the important strategic tools an organization employs is training and development to enhance the performance of human resources (Falola, Osibanjo, \& Ojo, 2014). Similarly, Edralin (2004) demonstrated that training is an indispensable tool that can be used strategically to improve the performance of human resources by adapting to the changes in both external and internal environments. According to Vemić (2007), organizational survival is reliant on how frequently training and development opportunities are provided to employees because it can lead to creating human resources more creative and productive. Thus, to handle the changes effectually that are happening at a fast pace; thus, training and development have now turned out to be a necessary intervention to inculcate the knowledge and skills to deal with the adversity (Singh \& Shukla, 2018).

So, training and development are not only confined to knowledge acquiring, skills as well as abilities improvement, yet it also helps employees regarding the adaptation of changes along with modification in their attitude as well (Ikač, 2006). Correspondingly, Wilder, Collier, \& Barnes (2014) also shared the same view that modification of behavioral standpoint of employees as per the vicissitudes $\mathrm{n}$ the environment is one of the most important aspects of their performance. Kumar \& Siddika (2017); Noe \& Kodwani (2018) and Vukotić, Karabašević, Mirčetić, \& Maksimović (2019) postulates the corresponding views that the provision of training and development can act as an effective way to improve the skills and competency of employees by enabling them to adapt to the modification. Besides, due to the availability of development opportunity, people feel happy about his or her job when their growth need is fulfilled particularly when confronting the changes in the workplace ultimately results in better performance (Rezwanullah \& Ahmad, 2018).

For an organization to gain a competitive advantage, human resources play a requisite role because their competency, skills, knowledge, and abilities help the organization to go through the 
turbulent changes while the role of human resources can be made more effective by using training and development practices (Armstrong, 2010; Houger, 2006; Tahir, Yousafzai, Jan, \& Hashim, 2014). Congruently, Hendri (2019) asserted that to attain a competitive advantage, organizations require positive behavior from employees to attain the predetermined goals. This is possible when organizations set priorities for the development of human resources which fallouts in more positive thinking among employees as the organization value them. Hence, when people satisfy with their organizational practices result in better performance along with the demonstration of positive behavior (Pradhan, Dash, \& Jena, 2017).

The other issue that affects management practices is the presence of organizational politics. According to Jhatial, Cornelius, \& Wallace (2014), when the use of power and politics is predominantly overly influenced by the decisions related to HR practices which in turn affect the performance of human resources. Encompassing this sight, Byrne, Manning, Weston, \& Hochwarter (2017) also specified that it is important to comprehend whether organizational politics can lead to fabricating positive or negative outcomes at work. Though mixed shreds of evidence are found in the literature associated with the effect of the organization politics on work-related outcomes such as a negative connection of organization politics with satisfaction at job exist along with the existence of a positive relationship with job stress, burnout, and turnover intention (Labrague et al., 2017). Furthermore, Nadeem, Ahmad, Ahmad, Batool, \& Shafique (2015) stipulates that the predilections employee receives from top management can have a substantial effect on satisfaction level; as a result, human resources performance can be enhanced.

\section{Problem Statement}

In the service sector, the timely execution of training and development opportunities, and compensation is the main area of apprehension (Santos, 2019). Similarly, Wahab, Hussain, Zadeh, Shah, \& Hussain (2014) shared the parallel argument that there is a lack of a systematic approach related to the training and development of employees which eventually affects human resources performance in hospitals. Consistently, the presence of nepotism and favoritism is an area of concern for healthcare professionals during the implementation of HR practices (Mahmood, 2014; Times, 2018). Sarwar \& Imran (2019) also anticipated that the grave issues of nepotism \& favoritism prevailing in Pakistan need to be investigated with other factors. Thus, keeping this gap in view to see the most obvious manifestation of organizational politics in our culture is the presence of nepotism and favoritism. While there is a scarcity of studies related to how nepotism and favoritism as a form of organization politics affect the link between training and development and employee performance dimensions.

Therefore, to discourse this gap this study attempts to investigate the effect of training and development on adaptive performance and contextual performance along with nepotism and favoritism as a mediator in public sector hospitals of Pakistan. In the current study, employee performance is measured through adaptive performance and contextual performance. Moreover, training and development are used as a predictor to predict adaptive performance and contextual performance while organizational politics in terms of nepotism as well as favoritism are used as a mediator. So, this study examines the conceptual model grounded on the social exchange theory, which offers that worker receive favors results to repay a favor with favor to get the additional favors and sustenance from higher-ups (Blau, 1964). According to Fletcher (2001) and Javidmehr \& Ebrahimpour (2015), when the supervisor favors the workers will fallouts in more positive outcomes as compared to a negative one.

\section{REVIEW OF LITERATURE \\ Employee Performance}

Na-Nan, Chaiprasit, \& Pukkeeree (2018) avowed that job performance in the field of industrial \& organizational psychology has been well-thought-out as a considerable component in the life of human resources. Like, Ramawickrama, Opatha, \& PushpaKumari (2017) explained that job performance is the behavioral outcome related to the worker's positive attitudes towards the organization. Accordingly, by definition, the performance construct is a variable that distinguishes between two sets of behaviors, for instance, firstly, what people do or behave in different situations and secondly, the expected value in terms of what people do to attain the organizational goals (Motowidlo \& Kell, 2012). Compatibly, the first dimension of employee performance- adaptive 
performance refers to an individual capacity to solve novel problems that occur due to change in the environment (Charbonnier-Voirin \& Roussel, 2012). Similarly, Park \& Park (2019) stated that adaptive performance is viewed as a flexible work behavior corresponding to the situation that helps employees to adopt the changes through learning the new skills in order to solve problems, vagueness along with management of stress, and crisis control.

Secondly, contextual performance is another emerging dimension of employee performance nowadays because it enables employees to involve in organizational activities that contribute positively to the well-being of an organization (Nini, 2019). According to Rashid, Tasmin, Qureshi, \& Shafiq (2017), in a highly competitive environment, contextual performance is the supportive behavior of an individual which is not itemized in the scope of a job, whereas this kind of behavior is valuable for operations and performance of the organization. As per Scotter, Motowidlo, \& Cross (2000), contextual performance requires no minimum standard to support others. Similarly, DíazVilela et al. (2015) also delineated that contextual performance is also termed citizenship performance which involves voluntary positive behaviors that are not directly linked to the job task. So, employee performance is not restricted to just performing the assigned task.

\section{Training and Development}

Training is defined by Edralin (2004) as an organizational intervention to facilitate the learning of new skills and abilities that result in improvement in the attitude and performance level of employees on one side whereas development can help in the growth of human resources by acquiring the knowledge needed to fulfill the projected goals of an organization. Similarly, Kulkarni (2013) demonstrated that in the competitive world, training and development both play a remarkable role in enhancing the knowledge as well as the skills and capabilities of individuals working in a challenging environment. Accordingly, training and development can help employees to learn and improvise new information along with reinforcing the existing knowledge and skills. So, training plays a vital part in the current state of employment while development plays a vigorous part in the upcoming role of employee that further facilitates the link between employee and employer (Long, Kowang, Chin, \& Hee, 2016).

As per Shah, Hussain, \& Rahman (2016) explanation investments in the training and development of healthcare employees are one of the significant tools for enhancement of the employee's attitudes and behaviors. Plentiful activities are intricate in the training and development activity, for instance, refinement of skills and knowledge, clarification of concepts (Fatema, 2018), resulting in enriching the performance of employees. Hence, the main key to coping with changing demands of the health care system is training and development (Liang, Howard, Koh, \& Leggat, 2013); as a result of effective implementation of this practice numerous outcomes can be attained such as enhancement of employee performance, motivation, and satisfaction at the job (Ayeleke, North, Wallis, Liang, \& Dunham, 2016; Motlokoa, Sekantsi, \& Monyolo, 2018); along with the flexibility to cope with changes (Alshuwairekh, 2016).

Thus, training is a proactive method for the development of skills and expertise to prevent problems from intensifying whereas development refers to generating solutions to problems at work, earlier before it becomes an apprehension (Imran \& Tanveer, 2015). Moreover, Falola et al., (2014) explicated that training improves the ability of the employee and problem-solving skills along with improving employee performance, via enhancing the competencies, and skills (Amin et al., 2013; Diab \& Ajlouni, 2015; Sultana, Irum, Ahmed, \& Mehmood, 2012). So, Chen, Thomas, \& Wallace, (2005) unveiled in their study that training, as well as the development of skills, are related positively to the adaptive performance of an employee.

\section{Training and Development, Adaptive Performance and Contextual Performance in the Presence of Nepotism and Favoritism}

Organizational politics is defined as an act that permits workers to attain their objectives without going through the proper channels to track their self-centered benefits by the side of other employees which in turn leads to worsening the organizational and employee performance (Gull \& Zaidi, 2012). According to Ferris \& Treadway (2012), social networking in the organization can contribute to comprehending the presence of politics such as the employee can relate themselves based on kinship and friendship. Despite the fact due to the presence of politics several changes can be observed in individual behavior on one side; while it also causes conflict in relations between employees and employers on the other side (Firfiray, Cruz, Neacsu, \& Gomez-Mejia, 2018). Consistent with the 
above-mentioned arguments, nepotism and favoritism are seen as the aspect of political presence in the organization (Chukwuma, Agbaeze, Madu, Nwakoby, \& Icha-Ituma, 2019; Shneikat, Abubakar, \& Ilkan, 2016).

According to Eldor (2016), organization politics is regarded as a positive or negative phenomenon as it is reliant on the perception of employees how they view the whole phenomenon. In the current literature, the presence of politics is viewed positively on one hand, for illustration, politics can be seen as a challenge or sometimes as an opportunity intended for gaining additional resources as well as favors during the implementation of decisions related to HR (Albrecht \& Landells, 2012), which in due course specify the performance of an employee. Ishaq \& Zuilfqar (2014) also asserted that preferential treatment has now become a social custom associated with positive feelings rather than negative ones to favor blood relations and friends during the decisions related to HR practices. In the same disposition, preferential treatment to friends and family relations can be seen during the implementation of HR practices which as a result affect the job performance as asserted by authors like Ahmed, Baloch, \& Ghani (2015); Cacciattolo (2013); Kim (2004) and Shah, Ali, \& Ali (2015).

As highlighted by Erden \& Otken (2019) discrimination in the execution of HR practices based on preferential treatment corresponding to the appointment, delegation, assessment, rewards, training, and working conditions might result in affecting not only the employee job performance but also the organizational performance. Besides, Shoss, Witt, \& Vera (2012) found that conscientiousness and organizational politics together affect adaptive performance whereas Karatepe (2013) revealed that organizational politics affect extra-role (contextual) performance as well.

The effectual employment of training and development sessions is sightseen as a psychological pact among employers as well as employees; the performance of human resources can be affected positively and negatively based on equal availability of training and development programs to all the hired employees (Kuvaas, 2007). Katidjan, Pawirosumarto, \& Yuliani (2018) emphasized that training and development is the key to improving the staff performance by inculcating both hard as well as soft skills, relevant expertise, and social competence in terms of doing collaborative work with others through contributing voluntarily to the fulfillment of an organizational goal. As understanding and cooperating with colleagues is related to performing extra duties which are the main facet of contextual performance (Turnipseed \& Rassuli, 2005). Training and development also contribute to enhancing the dexterity towards collaborating with others at work (Devi \& Shaik, 2013; Ali, Shoukat, \& Kamran, 2016). Accordingly, Nwanzu \& Okolo (2017) found that training and development significantly influence contextual performance. Therefore, in the current study we have formulated the following hypotheses:

H1: Training and development affect the adaptive performance of employees.

$\mathrm{H} 2$ : Training and development affect the contextual performance of employees.

H3a: Nepotism mediates the relationship between training and development and the adaptive performance of employees.

H3b: Nepotism mediates the relationship between training and development and the contextual performance of employees.

H4a: Favoritism mediates the relationship between training and development and the adaptive performance of employees.

H4b: Favoritism mediates the relationship between training and development and the contextual performance of employees.

\section{MATERIAL AND METHODS}

In the current study, positivism was used as it is used in quantitative research to verify the evidence objectively (Pham, 2018; Ryan, 2018). While a positivist paradigm was used as it is evocative for quantitative research (Burrell \& Morgan, 1979). A deductive approach was used as hypotheses were developed (Zalaghi, 2016). So, the purpose of the study was to determine the link between training and development, adaptive performance, and contextual performance along with the mediating effect of organization politics in terms of nepotism and favoritism, therefore, explanatory research was used (Neuman, 2014). To attain this purpose, a survey strategy was used to collect relevant information from the respondents (Check \& Schutt, 2012).

The mono method was used that is quantitative (Saunders \& Thornhill, 2012). Data were collected at one point in time to estimate the outcomes of interest (Aggarwal \& Ranganathan, 2019). 
For the collection of data, first-hand information was used (Salkind, 2010). Data were analyzed using SPSS and AMOS by means of different techniques such as descriptive statistics, reliability statistics, confirmatory factor analysis, and structural equation modeling.

The target population of this study was comprised of healthcare professionals at work in the public hospital segment. In addition, a purposive sampling technique was used to collect data from the people who give us relevant information (Etikan, Musa, \& Alkassim, 2016). The data was congregated from the respondents with a sample of 379.

Demo, Neiva, Nunes, \& Rozzett (2012) items were taken to measure training and development. Besides, to quantify adaptive and contextual performance items were taken from Pradhan \& Jena (2017). Nepotism and favoritism were measured from items taken from Büte (2011). Participants were asked to reply on a five-point Likert scale to quantify their level of agreement and disagreement against each statement.

\section{RESULTS AND DISCUSSION}

\section{Demographic Profile of Respondents and Descriptive statistics}

In the sample, $57.5 \%(n=218)$ are male whereas $42.5 \%(n=161)$ are representing female. Furthermore, $19.5 \%$ of respondents were under 30 years of age, $46.2 \%$ were $31-40$ years of age, $22.7 \%$ were representing $41-50$ years of age and $11.6 \%$ were represented above 50 years of age. Similarly, $51.5 \%$ were representing the doctors as a respondent in the study whereas $48.5 \%$ were representing paramedical staff in the study. The descriptive statistics along with the skewness as well as kurtosis values of the variables are mentioned in Table 1 . According to the outcomes of the analysis, the mean value of training and development is 4.48. The highest value among other variables with Std. Dev of 0.713 . To check the pattern of data normality, all values fall within the range of \pm 1.5 for skewness and within the range of \pm 3 for kurtosis (Kim, 2013).

Table No. 1 Mean and Std. Deviation statistics

\begin{tabular}{lllll}
\hline Variables & Mean & Std. Deviation & Value of Skewness & Value of Kurtosis \\
\hline Training and Development & 4.48 & 0.713 & -0.584 & 0.318 \\
\hline Adaptive Performance & 4.21 & 0.772 & -0.890 & 0.851 \\
\hline Contextual Performance & 4.25 & 0.711 & -0.937 & 1.310 \\
\hline Nepotism & 4.37 & 0.636 & -0.531 & -0.644 \\
\hline Favoritism & 4.38 & 0.633 & -0.588 & -0.285 \\
\hline
\end{tabular}

\section{Measurement Model and Hypotheses Testing}

So, before hypotheses testing, it is important to assess the structure along with the validity of the constructs by performing confirmatory factor analysis. Furthermore, confirmatory factor analysis (CFA) is considered as a base for performing the structural model (Weston \& Gore, 2006). The results of this study specify the good model fitness based on the analysis of data as the values of RMSEA, IFI, TLI, and CFI fall with the proposed range. Besides, a confirmatory fit index greater than 0.95 specifies a psychometrically acceptable fit to data (Karadal \& Arasli, 2009). The Chi-square/df value $=1.095$ which is less than 5.0 demonstrates the model fitness. On the other side, there was no issue of validity as values are within the range.

\section{Table No. 2 Hypotheses Testing Using SEM}

\begin{tabular}{lllll}
\hline Hypotheses & $\begin{array}{l}\text { Standardized } \\
\text { Coefficients }\end{array}$ & $\begin{array}{l}\text { Un-Standardized } \\
\text { Coefficients }\end{array}$ & Standard Error & P-value \\
\hline H1 & .737 & .746 & .035 & $* * *$ \\
\hline H2 & .683 & .681 & .037 & $* * *$ \\
\hline
\end{tabular}

The direct relation between training and development, adaptive performance, and contextual performance is assessed by the standardized regression weights. Table 6 indicates the results linked to the hypothesized relation that training and development have a positive and substantial influence on adaptive performance and contextual performance as the value of $\mathrm{p}$ is $<0.005$. A positive and substantial link has been established between training and development, adaptive performance among employees. The results are consistent with the existing literature (Amin et al., 2013; Chen et al., 2005; Diab \& Ajlouni, 2015). In addition, a positive, as well as considerable result, has been established 
between training and development, and contextual performance of employees. The results of the study are as per the existing literature (Ali et al., 2016; Devi \& Shaik, 2013; Nwanzu \& Okolo, 2017).

\begin{tabular}{llllll} 
Table No. 3 & \multicolumn{2}{l}{ Mediation Analyses } & & & \\
\hline Hypotheses & $\begin{array}{l}\text { Direct } \\
\text { Effect }\end{array}$ & $\begin{array}{l}\text { Indirect } \\
\text { Effect }\end{array}$ & $\begin{array}{l}\text { Lower Limit } \\
\text { Confidence Interval }\end{array}$ & $\begin{array}{l}\text { Upper Limit } \\
\text { Confidence Interval }\end{array}$ & P- Value \\
\hline H3a & .346 & .392 & .337 & .449 & .001 \\
\hline H3b & .275 & .408 & .349 & .470 & .001 \\
\hline H4a & .361 & .381 & .325 & .440 & .001 \\
\hline H4b & .291 & .391 & .332 & .452 & .001 \\
\hline
\end{tabular}

Table 3 designates the results related to the mediating effect. Based on the results, it turns out to be apparent that among a lower and upper limit of CI zero does not be present (Preacher \& Hayes, 2008). Consequently, the incorporated mediators: nepotism, and favouritism mediate the association between training and development, adaptive performance, and contextual performance. It also becomes evident that nepotism and favoritism as mediating variables have a meaningful impact on the association between training and development, adaptive performance, and contextual performance. It is consistent with the literature that the preferred individual responds to the good turn through displaying gratefulness, faithfulness, and optimistic behavior through signifying a higher level of performance (Dağli \& Akyol, 2019). These results illustrate that organizational politics dimension: nepotism and favoritism have nowadays become a culturally tolerable custom in a collectivist culture where individuals feel contented to get favors from the higher-ups or people in authority (Ishaq \& Zuilfqar, 2014).

\section{CONCLUSION}

As per the results of the study, it is concluded that a strong link exists between training and development, adaptive and contextual performance. Therefore, results portray that during executing the training and development practices management must be cautious to timely organize the programs as per the needs of employees as it eventually affects the employee's performance. Social exchange theory was used as a means to make a link of training and development with the employee's outcomes such as adaptive performance and contextual performance in the presence of organization politics. Furthermore, it is concluded that nepotism and favoritism during the implementation of training and development reciprocate in positive fallouts such as adaptive performance and contextual performance. This means that nepotism and favoritism are seen as positive aspects in the organization resulting in portraying positive results. Thus, the apprehension of organization politics is seen as an important element to repay the positive favor with a positive contribution to the organization.

\section{Limitations and Recommendations}

The existing study is of worth for the managers who manage human resources of the hospital towards framing a strategy to rheostat this phenomenon in the organization as it eventually determines the employee performance. Likewise, there are some limitations present in the current study. Primarily, training and development are considered in the current study among other HR practices, future investigators should deliberate other HRM practices to further widen the prospect. Then, data were congregated at one point in time. So, future investigators ought to demeanor a study from the longitudinal view to increase the perspective of the results.

\section{REFERENCES}

Aggarwal, R., \& Ranganathan, P. (2019). Study designs: Part 2 - Descriptive studies. Perspectives in clinical research, 10(1), 34-36.

Ahmed, M., Baloch, A., \& Ghani, H. (2015). The Impact Of Organizational Politics On The Productivity Of Employees: An Empirical Investigation From Pakistan. Gomal University Journal of Research, 31(2), 122-133.

Albrecht, S. L., \& Landells, E. M. (2012). Organizational politics and occupational health psychology: A demands-resources perspective. (S. L. J. Houdmont, \& R. R. Sinclair Ed.): Wiley-Blackwell. 
Ali, S., Shoukat, F., \& Kamran, A. (2016). Impact of Training \& Development on the Performance of the Employees of Silk Bank Limited-Karachi East Division Branches. Paper presented at the International Conference on Economics and Management.

Alshuwairekh, D. K. N. (2016). The Effectiveness Of The Training Programs On Employees Performance: An Empirical Study At Private Sector Companies In Saudi Arabia. International Journal Of Business And Management Review, 4(9), 1-23.

Amin, A., Saeed, R., Iqbal, A., Lodhi, R. N., Simra, M., \& Tehreem, R. (2013). The Impact of Employees Training On the Job Performance in Education Sector of Pakistan. Middle-East Journal of Scientific Research, 17(9), 1273-1278.

Armstrong, M. (2010). A Handbook of Performance Management (4 ed.). London: Kogan Page Limited.

Ayeleke, R. O., North, N., Wallis, K. A., Liang, Z., \& Dunham, A. (2016). Outcomes and Impact of Training and Development in Health Management and Leadership in Relation to Competence in Role: A Mixed-Methods Systematic Review Protocol. International Journal of Health Policy and Management, 5(12), 715-720.

Blau, P. M. (1964). Exchange and Power in Social Life: New York: Wiley.

Burrell, G., \& Morgan, G. (1979). Sociological paradigms and organisational analysis: elements of the sociology of corporate life (Reprinted): Farnham: Ashgate.

Büte, M. (2011). The Effects of Nepotism and Favoritism on Employee Behaviors and Human Resources Practices: A Research on Turkish Public Banks. TODAĐE's Review of Public Administration, 5(1), 185-208.

Byrne, Z. S., Manning, S. G., Weston, J. W., \& Hochwarter, W. A. (2017). All Roads Lead to WellBeing: Unexpected Relationships Between Organizational Politics Perceptions, Employee Engagement, and Worker Well-Being (C. C. Rosen \& P. L. Perrewé ed. Vol. 15): Emerald Publishing Limited.

Cacciattolo, K. (2013). Organisational Politics and Their Effect on Workplace Learning. European Scientific Journal, 4, 198-211.

Charbonnier-Voirin, A., \& Roussel, P. (2012). Adaptive Performance: A New Scale To Measure Individual Performance In Organizations: Adaptive Performace: A New Scale To Measure Individual Performance. Canadian Journal of Administrative Sciences, 29(3), 280-293.

Check, J., \& Schutt, R. K. (2012). Survey research. Thousand Oaks, CA: Sage Publications.

Chen, G., Thomas, B., \& Wallace, J. C. (2005). A multilevel examination of the relationships among training outcomes, mediating regulatory processes, and adaptive performance. Journal of Applied Psychology, 90(5), 827- 841.

Chukwuma, I., Agbaeze, E., Madu, I., Nwakoby, N., \& Icha-Ituma, A. (2019). Effect Of Nepotism On Employee Emotional Engagement: Interplay Of Organisational Politics. Journal of Management Information and Decision Sciences, 22(3), 273-283.

Dağli, A., \& Akyol, Z. (2019). The Relationship between Favouritism Behaviours of Secondary School Administrators and Organizational Commitment of the Teachers. Journal of Education and Training Studies, 7(7), 35-49.

Demo, G., Neiva, E. R., Nunes, I., \& Rozzett, K. (2012). Human resources management policies and practices scale (HRMPPS): exploratory and confirmatory factor analysis. Brazilian Administration Review, 9(4), 395-420.

Devi, D. V. R., \& Shaik, M. N. (2013). Measurement Of Training \& Development Effectiveness- An Empirical Study. Asia Pacific Journal of Marketing \& Management Review, 2(9), 12-18.

Diab, S. M., \& Ajlouni, M. T. (2015). The Influence of Training on Employee's Performance, Organizational Commitment, and Quality of Medical Services at Jordanian Private Hospitals. International Journal of Business and Management, 10(2), 117-127.

Díaz-Vilela, L. F., Delgado Rodríguez, N., Isla-Díaz, R., Díaz-Cabrera, D., Hernández-Fernaud, E., \& Rosales-Sánchez, C. (2015). Relationships between Contextual and Task Performance and Interrater Agreement: Are There Any? . PloS One, 10(10), 1-13.

Edralin, D. M. (2004). Training: A strategic HRM function. Centre for Business and Economic Research and Development, 7(4), 1-4. 
Eldor, L. (2016). Looking on the Bright Side: The Positive Role of Organisational Politics in the Relationship between Employee Engagement and Performance at Work. Applied Psychology, 66(2), 233-259.

Erden, P., \& Otken, A. B. (2019). The Dark Side of Paternalistic Leadership: Employee Discrimination and Nepotism. European Research Studies Journal, XXII(2), 154-180.

Etikan, I., Musa, S. A., \& Alkassim, R. S. (2016). Comparison of Convenience Sampling and Purposive Sampling. American Journal of Theoretical and Applied Statistics, 5(1), 1-4.

Falola, H. O., Osibanjo, A. O., \& Ojo, I. S. (2014). Effectiveness of training and development on employees' performance and organisation competitiveness in the nigerian banking industry. Bulletin of the Transilvania University of braşov, 7(1), 161-170.

Fatema, N. (2018). Stimulation of Efficient Employee Performance through Human Resource Management Practices: A Study on the Healthcare Sector of Bangladesh. International Journal of Business and Social Research, 08(01), 01-18.

Ferris, G. R., \& Treadway, D. C. (2012). Politics in organizations: theory and research considerations. New York: Routledge, Taylor \& Francis Group.

Firfiray, S., Cruz, C., Neacsu, I., \& Gomez-Mejia, L. R. (2018). Is nepotism so bad for family firms? A socioemotional wealth approach. Human Resource Management Review, 28(1), 83-97.

Fletcher, C. (2001). Performance appraisal and management: The developing research agenda. Journal of Occupational and Organizational Psychology, 74, 473-487.

Gull, S., \& Zaidi, A. A. (2012). Impact of Organizational Politics on Employees' Job Satisfaction in the Health Sector of Lahore Pakistan. Interdisciplinary Journal Of Contemporary Research In Business, 4(2), 156-170.

Hendri, M. I. (2019). The mediation effect of job satisfaction and organizational commitment on the organizational learning effect of the employee performance. International Journal of Productivity and Performance Management, 68(7), 1208-1234. doi:10.1108/IJPPM-05-20180174

Houger, V. P. (2006). Trends of employee performance. Collaborative effort between managers and employees. International Society for performance improvement, 45(5), 26-31.

Ikač, N. (2006). Menadžment ljudskih resursa. Novi Sad: Fakultet tehničkih nauka.

Imran, M., \& Tanveer, A. (2015). Impact Of Training \& Development On Employees' Performance In Banks Of Pakistan. European Journal of Training and Development Studies, 3(1), 22-44.

Ishaq, H. M., \& Zuilfqar, A. (2014). To Investigate The Moderating Role Of Favoritism On Employees Motivation. Science International, 26(1), 347-351.

Javidmehr, M., \& Ebrahimpour, M. (2015). Performance appraisal bias and errors: The influences and consequences. International Journal Of Organizational Leadership, 4(2015), $286-302$.

Jhatial, A. A., Cornelius, N., \& Wallace, J. (2014). Rhetorics and realities of management practices in Pakistan: Colonial, post-colonial and post-9/11 influences. Business History, 56(3), 456-484.

Karadal, H., \& Arasli, H. (2009). The impacts of superior politics on frontline employees' behavioral and psychological outcomes. Social Behavior and Personality: an international journal, $37(2), 175-190$.

Karatepe, O. M. (2013). Perceptions of organizational politics and hotel employee outcomes: The mediating role of work engagement. International Journal of Contemporary Hospitality Management, 25(1), 82-104.

Katidjan, P., Pawirosumarto, S., \& Yuliani, T. (2018). The Effect of Competence, Training, and Compensation to Employment Performance. European Research Studies Journal, XXI(3), 280-292.

Kim, H.-Y. (2013). Statistical notes for clinical researchers: assessing normal distribution (2) using skewness and kurtosis. Restorative dentistry \& endodontics, 38(1), 52-54.

(2004). The Influence of Organizational Politics and Power on Training Transfer. Paper presented at the Midwest Research to Practice Conference in Adult, Continuing, and Community Education.

Kulkarni, P. P. (2013). A Literature Review On Training \& Development And Quality Of Work Life. Journal of Arts, Science \& Commerce, 4(2), 136-143. 
Kumar, D., \& Siddika, H. (2017). Benefits of Training and Development Program on Employees' Performance: A Study with Special Reference to Banking Sector in Bangladesh. International Journal of Research-Granthaalayah, 5(12), 77-88.

Kuvaas, B. (2007). An Exploration of How the Employee?Organization Relationship Affects the Linkage Between Perception of Developmental Human Resource Practices and Employee Outcomes. Journal of Management Studies, 45(1), 1-25.

Labrague, L. J., McEnroe-Petitte, D. M., Gloe, D., Tsaras, K., Arteche, D. L., \& Maldia, F. (2017). Organizational politics, nurses' stress, burnout levels, turnover intention and job satisfaction. International Nursing Review, 64(1), 109-116.

Liang, Z., Howard, P. F., Koh, L. C., \& Leggat, S. (2013). Competency requirements for middle and senior managers in community health services. Australian Journal of Primary Health, 19(3), 256-263.

Long, C., Kowang, T., Chin, T., \& Hee, O. (2016). Improving Organizational Performance through Training Function: A Review. International Business Management, 10(4), 475-478.

Mahmood, A. (2014, November 17). Of nepotism. Retrieved from http://www.dawn.com/news/1144978

Motlokoa, M. E., Sekantsi, L. P., \& Monyolo, R. P. (2018). The Impact of Training on Employees' Performance: The Case of Banking Sector in Lesotho. International Journal of Human Resource Studies, 8(2), 16-46.

Motowidlo, S., \& Kell, H. (2012). Job Performance. In Neal W. Schmitt \& S. Highhouse (Eds.), Industrial and organizational psychology (Vol. 12, pp. 82-103): Wiley.

Nadeem, M., Ahmad, R., Ahmad, N., Batool, S. R., \& Shafique, N. (2015). Favoritism, nepotism and cronyism as predictors of job satisfaction: Evidences from Pakistan. Journal of Business and Management Research, 8 224-228.

Na-Nan, K., Chaiprasit, K., \& Pukkeeree, P. (2018). Factor Analysis-validated Comprehensive Employee Job Performance Scale. International Journal of Quality \& Reliability Management, 35 (10), 2436-2449.

Neuman, W. L. (2014). Social research methods:Qualitative and Quantitative Approaches (7 ed.). Harlow: Pearson.

Nini, M. (2019). Job Performance from an Evidence-based Management Perspective: Why Task and Contextual Performance Matters. CQNet. Retrived from https://www.ckju.net/en/dossier/JobPerformance-Evidence-based-Management-Perspective-Why-Task-and-ContextualPerformance-Matters/1258

Noe, R. A., \& Kodwani, A. D. (2018). Employee training and development (7 ed.): McGraw-Hill Education.

Nwanzu, C. L., \& Okolo, O. C. U. (2017). Influence Of Training And Development On Job Performance Among Non-Academic Staff Of Delta State Polytechnic, Ogwashi-Uku, Nigeria. . African Journal For The Psychological Study Of Social Issues, 20(2), 177-187.

Park, S., \& Park, S. (2019). Employee Adaptive Performance and Its Antecedents: Review and Synthesis. Human Resource Development Review, 1-31.

Pham, L. (2018). A Review of key paradigms: positivism, interpretivism and critical inquiry: University of Adelaide.

Pradhan, R. K., Dash, S., \& Jena, L. K. (2017). Do HR practices influence job satisfaction? examining the mediating role of employee engagement in Indian public sector undertakings. . Global Business Review, 20(1), 1-14.

Pradhan, R. K., \& Jena, L. K. (2017). Employee Performance at Workplace: Conceptual Model and Empirical Validation. Business Perspectives and Research, 5(1), 69-85.

Preacher, K. J., \& Hayes, A. F. (2008). Asymptotic And Resampling Strategies For Assessing And Comparing Indirect Effects In Multiple Mediator Models. Behavior Research Methods, 40 (3), 879-891.

Ramawickrama, J., Opatha, H. H. D. N. P., \& PushpaKumari, M. D. (2017). A Synthesis towards the Construct of Job Performance. International Business Research, 10(10), 66-81.

Rashid, M., Tasmin, R., Qureshi, M. I., \& Shafiq, M. (2017). Relationship Of Servant Leadership With Employee Inrole And Extra-Role Performance In GLC'S Of Malaysia. City University Research Journal(Special Issue: AIC, Malaysia), 88-95. 
Rezwanullah, \& Ahmad, S. Z. (2018). The Effect of Organizational Politics on Job Stress; Mediating Role of Job Satisfaction. Electronic Journal of Business Ethics and Organization Studies 23(2), 13-23.

Ryan, G. (2018). Introduction to positivism, interpretivism and critical theory. Nurse Researcher, 25, 14-20.

Salkind, N. J. (2010). Primary Data Source: Sage.

Santos, L. M. (2019). Rural Public Health Workforce Training and Development: The Performance of an Undergraduate Internship Programme in a Rural Hospital and Healthcare Centre. International journal of environmental research and public health, 16(7), 1-24.

Sarwar, A., \& Imran, M. K. (2019). Exploring Women's Multi-Level Career Prospects in Pakistan: Barriers, Interventions, and Outcomes. Frontiers in psychology, 10, 1-19.

Saunders, M., \& Thornhill, A. (2012). Research methods for business students. England: Pearson Education Limited.

Scotter, J. V., Motowidlo, S., \& Cross, T. C. (2000). Effects of task performance and contextual performance on systemic rewards. The Journal of applied psychology, 85(4), 526-535.

Shah, F. A., Hussain, J., \& Rahman, W. (2016). The Effect of Training and Development Practices on Employees' Organizational Commitment among the Employees in Private Health Care Sector in Khyber Pakhtunkhwa, Pakistan. Sarhad Journal of Management Sciences, 2(1), 17-26.

Shah, S. K. A., Ali, N., \& Ali, Z. (2015). Declining Employee Performance in Public Sector Organizations: An Etiological Study of Public Sector Organizations in Pakistan. Journal for Studies in Management and Planning, 01(05), 55-64.

Shneikat, B., Abubakar, A., \& Ilkan, M. (2016). Impact of Favoritism/Nepotism on Emotional Exhaustion and Education Sabotage: As Moderated by Gender. Paper presented at the Fourth 21st Century Academic Forum Conference At Harvard University, At Harvard University, Boston, USA.

Shoss, M. K., Witt, L. A., \& Vera, D. (2012). When Does Adaptive Performance Lead To Higher Task Performance?: Adaptive Performance. Journal of Organizational Behavior, 33(7), 910924.

Singh, A., \& Shukla, T. (2018). Role of Training and Development on Work Proficiency: Employee Perspective. Paper presented at the International Conference on Management and Information Systems September.

Sultana, A., Irum, S., Ahmed, K., \& Mehmood, N. (2012). Impact Of Training On Employee Performance: A Study Of Telecommunication Sector In Pakistan. Interdisciplinary Journal Of Contemporary Research In Business, 4(6), 646-661.

Tahir, N., Yousafzai, I. K., Jan, S., \& Hashim, M. (2014). The Impact of Training and Development on Employees Performance and Productivity A case study of United Bank Limited Peshawar City, KPK, Pakistan. International Journal of Academic Research in Business and Social Sciences, 4(4), 86.

Times, T. S. (2018). Badin youths accuse local hospital of monopoly, nepotism; demand justice. Retrieved from http://www.thesindhtimes.com/health-and-fitness/badin-youths-accuse-localhospital-monopoly-nepotism-demand-justice/.

Turnipseed, D. L., \& Rassuli, A. (2005). Performance Perceptions of Organizational Citizenship Behaviours at Work: A Bi-Level Study Among Managers and Employees. British Journal of Management, 16, 231-244.

Vemić, J. (2007). Employee Training and Development and the Learning Organization FACTA UNIVERSITATIS Series: Economics and Organization, 4(2), 209-216.

Vukotić, S., Karabašević, D., Mirčetić, V., \& Maksimović, M. (2019). New dimensions of the importance of a creative work environment and its impact on the management of contemporary organizations. Škola biznisa(2), 113-129.

Wahab, S. R. A., Hussain, A., Zadeh, A. A., Shah, F. A., \& Hussain, J. (2014). Employees' Perception and Motivation Towards Training and Development Programmes in Health Sector of Pakistan: A Case Study of Khyber Pakhtun Khwa. Middle-East Journal of Scientific Research, 19(10), 1361-1367.

Weston, R., \& Gore, P. A. (2006). A Brief Guide to Structural Equation Modeling. The Counseling Psychologist, 34(5), 719-751. 
Wilder, K. M., Collier, J. E., \& Barnes, D. C. (2014). Tailoring to customers' needs: Understanding how to promote an adaptive service experience with frontline employees. Journal of Service Research, 17(4), 446-459.

Zalaghi, H. (2016). The Role of Deductive and Inductive Reasoning in Accounting Research and Standard Setting. Asian Journal of Finance \& Accounting, 8(1), 23-37. 